\title{
SEARCHINGS AFTER THE COGNITIVE CENTRE (THE CASE OF BELARUS)
}

\author{
Valery Yevarouski \\ Institute of Philosophy, \\ National Academy of Sciences of Belarus, \\ Surganova vulitza 1/2, 220072, Minsk, Belarus, \\ E-mail:valewr@gmail.com
}

\begin{abstract}
The article presents the comparative analysis of the process of construction of a new cultural space with its specific history and its cognitive geography, securing a firm, which foots the intrinsic centre. Belarusian cognitive map in particular and the Eastern European one in general have their own specifics of a description of social reality. Particularly, philosophical discourse is usually used here as a main way of interaction between subject and social reality.

First of all, the presentation aims at an investigation of the emergence of the Belarusian cognitive center through the writings of national intellectual history. This article intends to present the conceptual analysis of our recent attempts to re-conceptualize and to line up the contemporary Belarusian national space with related "big picture" of Belarusian thought.

Keywords: Belarusian cognitive map, cognitive geography, East European regionalism, genealogy of the national thought, meditative thinking, intellectual history of Belarus, principle of the methodological pluralism, multiculturalism, revolutionary democrats, romantic nationalism.
\end{abstract}

doi:10.3846/limes.2010.02

\section{Introduction}

"Map Me No Maps, Sir, My Head Is A Map, A Map Of The Whole World."

Henry Fielding 1730, Rape Upon Rape, Act 2,

Scene 5

The Belarusian cognitive map in particular and the Eastern European one in general have their own specific description of social reality. Particularly, philosophical discourse is usually used here as a main way of interaction between subject and social reality. This approach is quite tricky. On the one hand, the "meditative floating over reality" can provide the generalization, suitable for the Eastern European syncretic culture, but on the other hand, this floating does not care about any results of verification. It means that these local studies often break the recognized institutional scopes and their author pretends to some indeterminate position (like scientist-artistbetween). Nevertheless, such speculative-meditative results of social reality's reflection (despite of their doubtful status) are recognized legitimate in the space of East Europe and of NIS countries. 
We will try to find some "more positivistic" analogues for the speculative notions that are used in our local tradition. Particularly, we are planning to employ the concept of the "cognitive map" while observing the complicated and syncretic mental structure of Belarusian society. We will treat the cognitive map as a four-dimensional time-spatial structure that contains competing within its limits of different meta-geographies (Lewis, Wigen 1997) and meta-histories (White 1973). From Hayden White's point of view on historical narrative, (hi)story can vary, according to its aesthetical structure as any story: it can equally be a novel, a tragedy or a satire. Alternatively, with regard to an ideological position or world outlook of the philosopher/historian, it can be conservative, liberal, anarchic, humanistic, nationalistic, communist and so on. Several meta-geographies coexist here on a relatively narrow and united territory. They are based on historical narratives to be cardinally different due to their ways of constructions of the past. Under the circumstances of this instability, our social reality differs from the other ones that are functioning in less or more stable countries. Some images of some "classical European countries” (for example, Belgium and Netherlands) rather have a clear-cut image and a depth of penetration that mostly depend in a degree of erudition of any recipient. Those names are well known and even not very successful: Belarusian school-child can find Belgium or Netherlands on a map and remember some moments of its history. In other words, our native observers of classic Europe has their steady stereotype, which can play a role of a good ground for any discussions even in a situation of a lack of competence. Internationally, Belarus has no such a status of intelligibility and a successive explanatory tradition.

First of all, this paper aims at an investigation of the emergence of Belarusian cognitive center through the writing of national intellectual history. We intend to present the conceptual analysis of our recent attempts to re-conceptualize and to line up the contemporary Belarusian national space with related "big picture" of Belarusian thought. Concisely we may describe the paradigm of the contemporary European meta-geography as the frameworks where (a) measuring and calculation are preferred to reflections and meditation; (b) "my history" has priority over "our history"; (c) any sort of ideologization is considered as the main sin of any research approach; (d) historical memory limits itself to time of individual life.

Thinking about the requirement of "double objectivation" (to objectivize the act of objectivation and the objectivizing subject of Pierre Bourdieu (Bourdieu, Lamaison 1986: 112)), we should see two components in the historical text: the point of view of an author and the interpreted facts. National historiography, the empirical bases of historical narratives are various within frameworks of some Eastern European style, accordingly to tasks of historical job but the point of view for this whole aggregation is similar. On the contrary, the historical narrative is directed to the same empirical field but it is created, for example, within the limits of Belarusian culture and, first of all, differs from the similar Ukrainian product by the mythology or the point of view. Within the limits of historical narrative, for instance, some history of the national resurgence is usually a certain conceptual scheme for designing some empirical materials into the synthetic form, which should be convenient for the perception, discussion 
and interpretation. From this point, some models of the chain of events, on the one hand, contain the necessary tools for generalization of the facts, but on other hand, the image of this epoch is a myth, cemented in the conceptual scheme. Besides the scheme of epoch or events it is not invented each time for everyone historical writing. This scheme is a paradigmatic tool and as any paradigm, it is the general for the big series of similar statements. The given image is typologically similar in the different genres of historical creativity. There are researches, textbooks, the educational programs and standards.

\section{Europe-Eurasia-between: Belarusian cognitive map}

Even if we will not consider the scientific significance of any sort of "big picture" business, we can look at its importance for the educational and ideological purposes. These intentions are especially sounded in the realms of the becoming societies. The national states of Eastern Europe are continuing to invent themselves with creating uppermost their national myth, i.e. the most concrete and the most real appearance of existence without any deductions and reservations (Лосев 1990: 162).

The Belarusians are not alone in their experience of inventing of the cognitive maps and narrating of "the big historical pictures". In Eastern Europe, this field of the market of symbolic goods (Bourdieu 1973) is cultivated well by our neighbors - historians and philosophers from Ukraine and Lithuania (Plečkaitis 2004; Яковенко 1997). Thus the single ontological history of Eastern Europe is generating the qualitatively various types of interpretations through the different national narratives. The common philosophical, historical, political and legal heritage, which was formed within Eastern European spatiality from approximately the beginning of the 11th to the middle of the 19th century, on the one hand, admits valuable, shared and parted cultural tradition of the Lithuanian, Belarusian, Ukrainian and Polish nations (Еворовский 2006: 52). On the other hand, the descriptions of this heritage depend on national affiliation of the researchers who often represent the practically independent interpretations, which sometimes have to be crossed in the particular traits, but never in the cardinal sense.

For example, the intellectual history of Ukraine in its contemporary implementation is usually originated from Ilarion of Kiev's Sermon on Law and Grace and Prayer; the Belarus thought originates it from the Life of Saint Euphrasinya of Polatsk. The beginning of the Lithuanian intellectual tradition is started off with the school, which is founded in the Dominican monastery in Vilnius (Plečkaitis 2004). In terms of such a building of national narratives (for example, intellectual histories), the history of accumulations of differences seems a quite long; the sources of this history can be safely originated at least from the Early Middle Ages. However, such monumental histories, which carry out perfectly, for example, the ideological functions, are not always ready for the perception of the real phenomena, closer than the Dark Ages.

At the end of 2008, was published the first volume of the History of Philosophical and Political Thought of Belarus (Евароўскі et al. 2008) devoted to the Medieval 
period. This book was supervised by Institute of Philosophy of the National Academy of Sciences of Belarus. It begins the new series of publications, covering the "big picture" of the Belarusian thought from the ancient times up to nowadays.

The theoretical background of The Intellectual History of Belarus Research Project is based on the principle of the methodological pluralism, which I formulate in the following way (Евароўскі et al. 2008: 110-129). The each project member is free to use any methodological frameworks to lead his or her, solving the problem in a more attractive way. My reason to promote this principle rests on two important conditions. We can see the strongest heterogeneity in the Belarusian philosophical field. We find here the grandiose stochastic conglomeration of various intermediate social and political conditions, disembodied and unsystematic collections of different meta-narratives, meta-histories and meta-geographies. In such a way, all achievements and mistakes of 20th century's European intellectual tradition are mixed in one place. Thus in contemporary Belarusian sociological and philosophical communities, which we observe, dispute between Slavophils and postmodernists, the followers of structuralism and the orthodox Marxists, the adherents of nationalism and staunch supporters of globalization and liberal ideology. All these people discuss similar problems.

\section{Calculation versus meditation}

From the genesis perspective, the intellectual history of Belarusian national space is often described as the sluggishness of coexistence of a number of embryonic stereotypes, based on different fragments of historical memory - hailing from Old Rus', the Grand Duchy of Lithuania (GDL), the First Rzeczpospolita, Russian Empery, traditional peasantry and, of course, the demised Soviet Union (SU). The local metageographical level is marked out (a) of elements of archaic culture, which exist in the rural communities and which are mostly structured with the mythological pattern, based on agricultural and genealogical cycles; (b) of totalitarian type of thinking, which reflects reality through a prism of nostalgia on the lost Soviet reality (it is reconstructed as Gold Ages with opposing a contemporary dystopia); (c) of the rational mode of thinking, which considers our present situation through the progressive way of thinking. Within these rational frameworks someone tries to include our history in the all-European context; (d) chaotic orientations reflect the past as dissolving in the present. Additionally, all these patterns of historical memory, which are dominated here, present a phenomenon that is similar to a memory after the Holocaust. We mean here effluents of the perpetual and centuries-long massacres of our nation and the aboriginal ethnos that have foreran her.

The main methodological conclusion that can follow from this reasoning, is sequent about the exorbitant heterogeneity of our social reality (and all scientific fields have reflected it). This nascent (and therefore, syncretistic) substratum cannot be measured even with the highly sensitive social measurements, and this often used matter has became a cause of a shock of both of the institutional sociology and the positivistic historiography. 
How does one describe the indescribable? Society, which cognitive background is somewhere in the middle between a metaphor, a myth and a speculative reflection, demands for itself the approaches, which were at the same level of approximations and syncretistic as well as reflected social reality. Those methods should keep the immediate grasping along with the ability to the measurement. Incompatibility between the object and its research methodology has usually produced strong pessimism and this pessimistic locking approach is very probably to deal with disappointment over unsuspected phenomena, which are repeatedly uncovered by scientific research (Kuhn 1962/1970: 8). An anomaly, perceived by Thomas S. Kuhn, is essential for perceiving novelty. However, quite despite Kuhn, we think that failures in obtaining adequate knowledge about the post-Soviet social reality and the moments of its history never stem merely from the crisis of the current scientific paradigm of the Western calculative sociology and positivistic history and never testify to this crisis. The calculative mind-set is effective only inside the history of social reality, which is constructed, according to the same calculative pattern. The mental background of the contemporary East Europe and their Eurasian bordering areas are not calculative but meditative. It means that this social reality is another form of the "event of appropriation" (Martin Heidegger's Ereignis). In order to research the history of social reality, which is adequately based on the form of Ereignis, the calculative thinking of the calculative culture requires a phenomenological correction.

This meditative background usually oversteps the limits of the strong academic discourse due to all national projects, which were built according to the romantic pattern in Eastern and Central Europe (Simpson 1993; Anderson 2002: 6) and presupposed with the poetic sublimity and philosophical contemplations. Such sort of thinking about the project has much to do with a necessity of the ideological constructions of culture. Of course, the result will be some artificial formation. It is something like an architect restores a damaged building. Moreover, each authorized version of the national cultural revival absorbs, on the one hand, author's personal peculiarities - his educational degree, those local intellectual traditions which he belongs to, his sympathies and antipathies. On the other hand, these national narratives try to find their place between historical artifacts, put down the national heritage in their vision of "national destiny", in order to win a contest for being the national paradigm.

\section{Lyudz'mi zvatstsa ${ }^{1}$}

For the purposes of this article, the established nation can be conceptualized as a certain form of consolidation for the whole population of the certain territory. Here we can also speak about the interior center for the certain national space. This center can be provided, for example, about one core (uniting in itself the political, cultural and

\footnotetext{
1 Людзьмі звацича - In English: We are the people [another version of translation in English: To be called human!]. There are the words from Yanka Kupala' sonnet A xmo maм idзe? (And, Say, Who Goes There?). These words have come to be the main slogan of Belarusian national resurgence since the first quarter of the 20th century. English translation of the sonnet by Vera Rich (Kupala 2005a).
} 
sacral functions) or around some conglomerate of the other centers (when the political, cultural and sacral hearts are located differently). Imperial conditions of generalizations of some communities are presupposed with the system of centering to be more complicated. The structure of the imperial centering usually has some kind of hierarchy. Moreover, any version of history, constructed on the romantic sample, usually extolles itself as a unique as some special Sonderweg of the "unchanging national essence". So, alongside with the Russian soul of the Slavophils, Sarmatism of the Polish messianists, we find "the muzhik's lot" of the Belarusian revolutionary democrats. From this point of view, it is possible to consider three types of the genealogies, appropriated to the development of the romantic construction of Belarusian nation: a) invented genealogy of an imagined community ("origins") or, as the author of some narrative, builds the springs and makes the development of some national identity; b) genealogy of construction, or the ideological and philosophical background, rationally deduced from the structure of some national narrative; c) intellectual genealogy, or the intellectual or political community, generated by some author. This type of genealogy shows, how some formal and informal networks are developed, and as some figures influenced on one another and maintained by each other.

The contemplations about the Belarusian destiny and the origins of the contemporary cognitive map were resulted from these three genealogies in disparate positions. Thus, the genealogy has invited its worshippers into the primordial springs of the Belarusian culture with arguing about the centuries-old massacres. Analysing genealogy of construction, we can back through Adam Mickiewicz's Messianism to Johann Gottfried Herder's romantic inclinations. Quite the contrary, the intellectual genealogy, usually led from the multicultural environment of this area of the former lands of the Polish-Lithuanian Commonwealth, the Rzeczpospolita to the gulaged Krajowcy (the "Regionalists"), which had became a nutritious (and then forgotten) starting place both for Belarusian and Lithuanian versions of nationalisms.

Starting the book, Wacław Iwanowski and resurgence of Belarus Jerzy Turonek (Turonek 1992: 11-12) has cited a good legend about Iwanowski's (1880-1943) family, which was the eminent Belarusian politician, the publisher and the author of the first Belarus abc-book. Turonek wrote that he had heard this story from the old woman from Lebiodka Iwanowska (the Lida region): “I remember Iwanowskis' family. There were three brothers. Jury was the Polish, Wacław was the Belarusian, Tadeusz - the Lithuanian. When these brothers had met, everyone spoke in his own language and anyone could not understand other". This anecdotic way of the popular discourse, of course, should not be taken literally. We can assume that these three brothers had not forgotten the Polish, which they had learnt since the childhood, talked fluently by Russian for they had studied at the Russian universities. We should understand the Belarusians lived long time in their countryside of this among Belarusian speaking "Tuteishiya".

Nevertheless, you cannot get away from the facts, that each of three brothers has retained the memory about himself in the histories of Belarus, Poland and Lithuania. Wacław was one of the initiators of Belarusian resurgence. Jerzy Iwanowski was the prominent politician of the Second Rzeczpospolita, Tadeusz (Tadas Ivanauskas) was 
one of the organizers of Kaunas university and a member of the Lithuanian Academy of Sciences. And this miraculous family in the territory of the former GDL, of course, is not an exception.

Keeping in mind the similar transformation of self-identifications, which had taken a place approximately from the end of the 19th to the first quarter of the 20th century, we have some tendency. A certain community has not any clear identification, which started to ramify, that after October revolution has resulted in two national States (Belarus and Lithuania) and in the development of a certain part of elite with Warsawcentered orientation in this territory. And this process has not changed the plasticity throughout one or two generation; it has provided some opportunities of choosing, changing and even the inventing of some national self-identification. It means that this identification-building cannot be described with any historical narrative, pretending to obtain a longer history than the period of one or two generations of members of the local elite of the Russian Empire's Northwest Region. We speak here about a certain generality which we name conditional as germinal the proto-national kernel, which main feature was not any ethnic and linguistic preferences but the phenomenon of considering some cultural or political place as the "center of gravity". Minsk or Wilna strives in our case of Northwest region.

Besides, this local and autochthon elite of the Northwest region as a rule, firstly, was not mixed with the colonial Russian administration; secondly, by themselves from Warsaw-centered Poles; thirdly, it has stand out against a background of "the silent majority". We mean here that the so-called Tuteishiya, the Belarusian-speaking peasantry is identified primarily with their local village, identifying themselves as "people from here". For this reason, this stage of history, this part of a population, which cannot play any social roles and which was only considered as a certain motive to stir up various romantic and idealistic creativities (Wincenty Dunin-Marcinkiewicz) and then narodnik-type inspirations of Belarusian revolutionary-democrats.

\section{Searching for Belarus}

"Cease dreaming of a past far-famed in story / Your dreams cannot revive it to existence, / Give all your life, devotedly insistent / But you'll not welcome back those days of glory” (English translation of the sonnet see: Kupala 2005b).

It was written by Kupala in 1906 year. As this appeal follows Belarusian intelligentsia, it had made an attempt to begin the history of her own people from a blank page and to close the Russian-Polish discussion over the rights of the Old Rus' and the GDL heritage own.

Searching for a better fate of the Belarusian peasants and discovering the special peasant truth ${ }^{2}$, identified with the key structural elements of the first version of the national ideology as well as the Belarusian history. It was pictured here with the chronology of the centuries-old captivities and exploitations. We can speak also about the

\footnotetext{
${ }^{2}$ In Belarusian: мужыцкая праўда.
} 
strongly presentive history with the pronounced opposition between the present and the past. And this past was negated through the overcoming of all its forms for the sake of some Golden Age of free and true Belarusian nation's existence. Thus at the beginning of 20th century the Old Rus' and the GDL - that important temporal phase of the regional culture, where Belarusian nation had been nourished - were becoming the transient obstacles for a progress of some imaged primordial ethnic group, which supposedly was gathering its strength beyond the social and cultural surroundings. This intellectual evolution had found its logical closure in "Адвечным шляхам" Ignat Abdziralovič (Абдзіраловіч (Канчэўскі) 1921), where Belarusian identity was depicted as the being in between the of the East and the West, Russia and Poland, and where Belarusians were described as people, who were betrayed by its elite that had assumed "West" or "East" orientation: "We haven't become a Western nation, but haven't accepted Eastern culture either. By this time, we began to be named an obscured and savage nation. Nominally, we were considered Catholics or Orthodox, Moscow's and Russian or Polish citizens. However, in reality, it's turned out that we are poor Catholics and poor Orthodox, poor sons of "ојсzyzna" and "отечество" (some contraposition between Polish and Russian names of fatherland. $-V$. Y.). There are only the most ill and spiritually spoiled elements of our nation, such was szlachta (gentry) in recent times, and in our days those intelligentsias that have lost their touch with their people, with their Belarusian roots and have left the people by themselves. These people have lived for all alone. In spiritual spheres, they are still pagans. In the economic one they are still using out-of-date farm implements - wooden plow, harrow, millstone, and flail. They are still living in that eternal forest, which was sung of so appallingly by our Belarusian poet.

We find the radical attempts of history conceptualizations. Then, analysing the first experiments of the Belarusian Petit Lavisse writings, we can see that they try to present Belarusian national history as a complete process. Thus Mitrofan DovnarZapol'ski (1860-1930), one of the founders of Belarusian national historiography, wrote: "We constitute a nation that differs from other Russian nationalities by its language, ethnographical feathers and aggregate cultural way of life, which was formed historically. And only this circumstance already gives us the right to have an independent national existence... In historical terms we're representing a nation which is a province of Russian Empire only for 150 years” (Доўнар-Запольскі 2002: 87).

These words from the article of Dovnar-Zapol'ski' had been published in Kievan Belarusian Word determined both common spirit of his History of Belarus (ДовнарЗапольский 2003) and that methodological canon, which is dominating in the Belarusian historical narrations until now. From the other side, the lines cited above are not a simple history ascertainment; it is rather a version of comprehension of that social reality, which gave the mental background for Dovnar-Zapol'ski. On the one hand, we can observe here again a process when a certain narration about the past submits to contemporary cultural and political processes external to historical logic.

\footnotetext{
${ }^{3}$ In English: On the eternal path.
} 
On the other hand, this past becomes some kind of "asylum" for author's expectations that cannot be realized in the present. Thus the past becomes a predecessor for such a future version, which is wished to be by (hi)story authors.

Dovnar-Zapol'ski started on his own presumptive work on Belarusian history, when the Belarusian intelligentsia heads had been filled with the Romantism. The basis for the romantic ideas' embodiment was revolutionary democratism. Philosophical bases of Belarusian revolutionary democratism had been a subject of the longstanding and detailed researches, which were developed by Alfred Maikhrovich (1937-2004), the famous Belarusian philosopher and one of the founders of Belarusian philosophical school. He underlined the undoubted consequence of revolutionary-democratic tendencies for Belarusian social and political life, but accentuated that at the same time its inward structure had been ambivalent, heterogenic and contradictory. Particularly he wrote in his book Становление нравственного сознания (Майхрович 1997) [In English: Becoming of the moral consciousness]: "It's difficult to find what was the first - epochal-historical social need (the need which is peculiar to the whole European culture, though it has been becoming apparent here in different historical moments to destruct medieval classes, a need to show up oneself on history's arena and in the broad democratic masses' social life, or a specific need of nation's self-determination, that was seeping through the bosom of people's life, which was based on deep-laid processes of ethnic and mental crystallization, achievement of a new stage of national being's distinctness and consolidation” (Майхрович 1997: 127).

Here we see the main peculiarity of our national intellectual history that differs from other Central-European nations' narratives. This romantic intention of idealization on those social groups is also very important and typical for Belarusian culture. Here, at former territories of the GDL national ideas, by the way, also were created these two kinds of idealization of the values. The "Right" Polish gentry's court and enlightened peasant's hut have become principles for all nations' successor of the GDL (Belarusians, Lithuanian, Poles and Ukrainians) coming-to-be. But in the context of the problem of independent Belarusian nation's origins, it is necessary to say, that a gentry's court and its values gradually here were pushed out in a marginal sphere, and a "peasant's truth" and a "peasant's hut" headed the list. We quoted those phrases advisedly. It is obvious that szlachta's court could really express itself, its thoughts and feelings in literature, in the philosophical and political treatises. However, the situation with a "peasant's truth” was ambiguous. A real Belarusian peasant, who involved a heavy manual labor in a routine and lived in a patriarchal surrounding, was not able to introspection. Heavy and frequently ungrateful peasant's duty was, that "speechless majority" and herald would be undertaken by the same szlachta. Here one can find the core of the revolutionary democratism. Thus in Belarusian literature the figure of "educated muzhik" appears, which will bring the truth to the "obscured peasant", which had lived out his days in his village.

The early history of the new Belarusian literature is enclosed and perfectly well defined by Alfred Maikhrovich's tendencies to understand a mission of a creator as to be a lamp, which enlights the people in their name of freedom. However, here another plot gradually began to dominate: the clash between author's creative intentions 
and increasing soullessness of its surrounding. Thus "the image of man's life and destiny as obscured by misfortunes, torments and outer world's evil" (Майхрович 1997: 187) had taken place of the teacher-devotee surrounded by the grateful nation. In European intellectual history of the first twenty-years period of the last century such a perception of a world was not unique. In Western Europe Friedrich Nietzsche's philosophy enjoyed wide popularity. In Russia the books by Nikolai Berdyaev and Lev Shestov (Yevarouski 2004-2005) paved the way for existential perception of the world. Also in Belarusian literature the fatherland had been portrayed in increasing frequency as "забранный край" [In English: taken land], inhabited by its "aloof sons" (the Belarusian word - чужыниы), who served enemies and even were not comprehend it. In such a situation the person sticks all alone with the needless truth; all that is left to him is to try to overcome outer world with the help of the "ideal and resolute deed, which is peculiarity and motive force of try poet's spirit, that anticipates future, is fixed upon it" (Майхрович 1997: 127).

In 1919 the following lines came from the pen of Kupala: "Arise the prophet from our people / The windfall's conjurer / With wise words remove the spell from the people / With which it has been casted by the enemies" ${ }^{4}$ (Купала 1997: 65). This poem "arise" resembling Nietzsche's looking-for unites existential sense of solitude with messianic visions. Not the people, but rather the personality must deliver the human body from the economic and politic bondage, and to clea a human soul. Such was the last word in "First project of Belarus' revival" and there were no any subsequent evolutions due to Soviet rule.

\section{On the way of coming home}

"Homecoming is the return into the proximity of the source. But such a return is only possible for one who has previously, and perhaps for a long time now, borne on his shoulders as a wanderer the burden of the voyage..." Heidegger, "Remembrance of the Poet” (Heidegger 1949).

The prevailing feeling about Belarus throughout this fifteen-year period of independence has probably been the unbearable boredom of uncertainty. We often name our time as the post-Soviet reality. However, this prefix only indicates, that one the events follows another one. In our case, we simply acknowledge that we have continued to live on shattered pieces of the SU for 15 years, and we still have no idea how to use these ruins for erecting new and respectable life. The important thing, which complicates any-directed transition of Belarus, is post-totalitarian elements of social psychology deformed by realities of the collapse time of SU. We have not forgotten the subjects with the self-determined cogito and then the internal moral law, but the numbers transformed into the subjects and then considered as the most topical problem of further re-thinking ways of our national development.

\footnotetext{
4 In Belarusian: "Паўстань з народа нашага прарок / Праяваў бураломных варажбіт, / I мудрым словам скінь з народу ўрок / Якім быў век праз ворага спавіт”.
} 
However, we should not forget the remarkable peculiarity of Eastern European space trying to exceed these depressing limits. Here we meet again the so-called intelligentsia' syndrome, which includes both the peculiarities of discourse and the specific attitudes towards reality. A self who claims his/her rights to the absolute ideal (and practical in some cases) independence, who creates his/her self-governing idyllic in his/here own mind, finds himself/herself in some thinking place, that is defined as “virtual Belarus”. For instance, within the local intelligentsia' discourse, Belarus could be interpreted according to the post-colonial methodology as some museum of historical ruins (Бабкоў 2005). (The Kingdom of Belarus: interpretation of ruinsrunes.) Sometimes Belarus is comprehended as the Land Between - particular as the civilizational area that is determined by different external cultural centers with multiple contradictory effects, as some transit passage, which has anything to be said about, a part that it is a passage. As one of the outlets from a blind alley of the Land Between is regarded looking-for some aboriginal alternative, some primordial and native essence of Belarusian land (Санько 1997).

\section{Conclusions}

Our Belarusian analysis of the cognitive map displays that it supposes some versions of the development of our country. Stereotypes (are be described above) have been inscribed in the national bosom. They are as the "sacred idol" of a nation, which is thoroughly guarded. That is why national perceptions of us by our neighbors are inevitably stiff. An attempt to instruct the neighbors of some nation through the myths about its exclusive moral and glorious history, deserves only the sarcasm. However, to moan about our own inferiority (under-Europeanity, betweenness, creoliness) is not way out.

We think that Belarusians need to centre upon the national kernel. The concentration of the country (which ought to be understood in classical Prince Alexander Gorchakov's sense ${ }^{5}$ ) is on an agenda. Nation should lend an attentive ear to itself, its own concerns and historical roots - this is the first step towards overcoming the images of some transit zone, the "borderland", something that has not the own destiny and centre. In this point, the integral national history, the political and intellectual consolidation will be a powerful incentive to overcome inferiority complex of Belarusian nation; this complex was cultivated both from within and from without. Calming on this kernel, could be answering on Heidegger's task to return to the proximity of the source. Belarusian coming-home is delayed.

Constructing such a kernel should not be forgetten words of Heidegger, that are following those and which we had taken as the epigraph for the previous chapter: "... proximity to the source is a mystery”. The concrete human being not always wants to be adjusted to a Procrustean bed of some national narration. The person is probably above any "imaged society". Time for another step ought to come. Belarusians, who

\footnotetext{
5 "Russia is not angry, it is simply concentrating" - Gorchakov to European emissaries (1859).
} 
will not be afraid to lose their own territorial affiliation someday will be learning to perceive as normal the fact, that someone will decide to be simultaneously "true Belarusian”, the admirer of Russian literature, protector of Polish education and adherent of French postmodern philosophy. Many-sided society as the many-sided people can absorb and resemble many things, but the main one that ought not to contradict is homogeneity. One can identify a part of his essence with Moscow through literature; with Paris through philosophy; with Warszawa through education but for all that things the motherland's child is the citizen of Republic of Belarus. This will be the multiculturalism and linguistic pluralism with only the slightly Belarusian specific.

\section{References}

Anderson, P. 2002. “Internationalism: A Breviary”, New Left Review 14: 5-25.

Bourdieu, P.; Lamaison, P. 1986. "From Rules to Strategies: An Interview with Pierre Bourdieu", Cultural Anthropology 1 (1): 110-120. doi:10.1525/can.1986.1.1.02a00060

Bourdieu, P. 1973. “Le marché des biens symboliques“, L’Année Sociologique 22: 49-126.

Heidegger, M. 1949. "Remembrance of the Poet”, in Brock, W. (Ed.) Existence and Being.

Washington, D. C.: Regnery Gateway Company, 251-291.

Kuhn, T. 1962/1970. The Structure of Scientific Revolutions. Chicago: University of Chicago Press.

Kupala, Y. 2005a. "And, Say, Who Goes There” [online], [Last access: 20-11-2009]. Available from Internet: <http://kupala-library.iatp.by/bel_lit/authors/kupala/272-e_v_rich.pdf>.

Kupala, Y. 2005b. "Cease Dreaming of a Past Far-famed in Story...” [online], [Last access: 2011-2009]. Available from Internet: <http://kupala-library.iatp.by/bel_lit/authors/kupala/272e_v_rich.pdf>.

Lewis, M.; Wigen, K. 1997. The Myth of Continents. Berkeley, CA: University of California.

Plečkaitis, R. 2004. Lietuvos filosofijos istorija. T. 1. Vilnius: Kultūros, filosofijos ir meno institutas.

Simpson, D. 1993. Romanticism, Nationalism, and the Revolt against Theory. Chicago: University of Chicago Press.

Turonek, J. 1992. Wacław Iwanowski i odrodzenie Białomsi. Warszawa: WOW „Gryf Instytut Historii Polskiej AŃ”.

White, H. 1973. Metahistory: The Historical Imagination in Nineteenth-Century Europe. Baltimore: Johns Hopkins UP.

Yevarouski, V. 2004-2005. “Era ,przeklętych pytań - filozofia ,podziemia” i byt inteligencji pierwszej połowy wieku dwudziestego", Wspólnotowość i Postawa Uniwersalistyczna 4: 151-165.

Абдзіраловіч (Канчэўскі), I. 1921. Адвечным шляхам: Дасьледзіны беларускага сьветагляду. Вільня: Друк.

Бабкоў, I. 2005. Каралеўства Беларусь: Вытлумачэньні ру[і]наў. Менск: Логвінаў.

Довнар-Запольский, М. В. 2003. История Белоруссии. Минск: Беларусь.

Доўнар-Запольскі, М. 2002. "Кіеўская публіцыстыка М. В. Доўнар-Запольскага", Спадчьна 5-6: 82-106. 
Евароўскі, В. Б.; Майхровіч, А. С.; Новікаў, В. М.; Санько, С. І.; Тузава, Т. М.; Бабкоў, І. М.; Дзерман, А. В.; Конан, У. М.; Старасценка, В. У.; Падалінская, А. А. 2008. Гісторыя філасофскай і грамадска-палітычнай думкі Беларусі. Т. 1. Эпоха сярэднявечча. Мінск: Беларуская навука.

Еворовский, В. Б. 2006. "Польско-российское интеллектуальное соперничество в Беларуси и становление ее национального самосознания (век девятнадцатый): Опыт историкоантропологической реконструкции", in Pereswetoff-Morath, A.; Bjorling, F. (Eds.) Words, Deeds and Values: The Intelligencias in Russia and Poland during the Nineteenth and Twentieth Centuries. Lund: Slavica Lundensia, 51-54.

Купала, Я. 1997. Поўны збор творай. Мінск: Маст.

Лосев, А. 1990. “Философия имени”, в Лосев, А. Из ранних произведений. Москва: Издательство “Правда", 228-258.

Майхрович, А. С. 1997. Становление нравственного сознания: Из истории духовной культуры Беларуси. Минск: Беларус кнігазбор.

Санько, С. 1997. “Беларусь: Паміж поўднем і поўначчу, адставовыя складнікі аўтэнтычнага мэтапалітычнага дыскурсуб", Фрагмэнты. No. 3 [online], [Last access: 20-11-2009]. Available from Internet: <http://txt.knihi.com/frahmenty/frahmenty3.htm>.

Яковенко, Н. 1997. Нариси Історії Украӥни: 3 найдавніших часів до кіния XVIII ст. Київ: Генеза.

\title{
TYRINĖJIMAI PAGAL KOGNITYVINI CENTRA (BALTARUSIJOS ATVEJIS)
}

\author{
Valery Yevarouski
}

\begin{abstract}
Santrauka
Straipsnyje pristatoma naujos kultūrinès erdvès konstravimo proceso komparatyvistinė analizè ir kognityvinè geografija, ittvirtinant ir apsaugant jai būdingą vidini centrą. Baltarusijos kognityvinis žemèlapis konkrečiai ir Rytų Europos žemėlapis apskritai pasižymi specifiniu socialinès realybės atvaizdavimu. Filosofinis diskursas šiuo atveju paprastai pasitelkiamas kaip pagrindinis subjekto ir socialinès realybès sąveikavimo būdas.

Straipsnio tikslas - pirma, pristatyti Baltarusijos kognityvinio centro iškilimą per nacionalinės intelektualiosios istorijos rašymą. Antra, aptarti nūdienių pastangų iš naujo konceptualizuoti ir apibrèžti Baltarusijos nacionalinę erdvę bei su ja susijusio baltarusiškosios minties „didžiojo paveikslo“ analizę.

Reikšminiai žodžiai: Baltarusijos kognityvinis žemèlapis, kognityvinė geografija, Rytų Europos regionalizmas, tautinès minties genealogija, meditatyvinis mąstymas, Baltarusijos intelektualioji istorija, metodologinio pliuralizmo principas, daugiakultūriškumas, revoliuciniai demokratai, romantinis nacionalizmas.
\end{abstract}

